\title{
Effect of Early and Split Weaning on Carcass traits of Large White Yorkshire Piglets
}

\author{
I. Ramyasree $^{1 *}$, P. Asha Latha ${ }^{1}$, Ch. Venkata Seshaiah ${ }^{2}$ and D. Srinivas Kumar ${ }^{3}$ \\ ${ }^{1}$ Department of Livestock Production Management, ${ }^{2}$ Department of ILFC, \\ ${ }^{3}$ Department of Nutrition, N.T.R College of Veterinary Science, Gannavaram, Krishna \\ District, Andhra pradesh, India \\ *Corresponding author
}

Keywords

Early weaning, Split weaning, Dressing percentage and

Meat-Bone ratio

Article Info

Accepted:

22 April 2021

Available Online:

10 May 2021
A study was carried out in 30 Large White Yorkshire piglets to find out the effect of early and split weaning on carcass characteristics. Four weaning age groups, 56 days of conventional weaning age as group $1(n=8)$, early weaning of entire litter at 28 days as group $2(n=10)$, split weaned piglets with heavy litter weaned at 28 days as group $3(n=6)$, weak litter left with sow up to 56 days as group $4(n=6)$ were compared. By the end of study period pigs were slaughtered and the carcass traits studied included dressing percentage and Meat: Bone ratio. The dressing per cent is significantly low in $2^{\text {nd }}$ group of piglets $(73.29 \pm 0.51)$ compared to $1^{\text {st }}$ $(78.14 \pm 0.91), \quad 3^{\text {rd }}(76.49 \pm 0.53)$ and $4^{\text {th }}(77.91 \pm 0.25)$. However no significant difference in dressing per cent was observed among $1^{\text {st }}, 3^{\text {rd }}$ and $4^{\text {th }}$ group piglets. The meat:bone ratio is significantly high in $3^{\text {rd }}$ group of piglets $(3.20 \pm 0.02)$ compared to $1^{\text {st }}(3.07 \pm 0.06), 2^{\text {nd }}(3.03 \pm 0.05)$ and $4^{\text {th }}$ $(2.80 \pm 0.05)$.

\section{Introduction}

Swine rearing is a profitable venture as this species is very prolific and is good source of meat. In India, the demand and awareness towards nutrition is increasing day by day with increasing human population. Out of $60 \mathrm{~g}$ of daily protein requirement as per Indian Council of Medical Research recommendation, about $20 \mathrm{~g}$ should be from animal protein source. But in India animal protein consumed per capita per day is less than $10 \mathrm{~g}$ which is lower than the requirement. So, in order to meet the protein demand, alternate meat production apart from chicken and mutton is required. Now-a-days, pork production gained momentum which has both good nutritional status and also economical 
value. There is a need for scientific pig farming along with post-slaughter pork processing and development of products with improved shelf-life to promote the pork industry in India. The aim of present study is to explore the economic advantage of early or split weaning in comparison to conventional weaning in commercial swine production.

\section{Materials and Methods}

Four weaning age groups, 56 days of conventional weaning age as group 1, early weaning of entire litter at 28 days as group 2 , split weaned piglets with heavy litter weaned at 28 days as group 3, weak litter left with sow up to 56 days as group 4 were compared. The piglets were fed with pig creep, grower and finisher rations in ad libitum basis. By the end of the study period pigs were fasted for 24 hours with free access to water ad libitum and then slaughtered as per the standard procedure (USDA, 1970) for carcass analysis. Dressing percentage of slaughtered animals was calculated by using the following formula

Weight of the hot carcass X 100

Pre slaughter weight

Meat bone ratio was calculated by separating the meat from the bone.

\section{Statistical analysis}

The data were subjected to one way ANOVA using a software package SPSS for statistical significance as per the methods laid down by Snedecor and Cochron (1995).

\section{Results and Discussion}

Significant differences $\quad(\mathrm{P}<0.01)$ were observed in dressing per cent and meat- bone ratios among different groups of piglets (Table $1)$. The dressing per cent is high in $1^{\text {st }}$ group piglets followed by $4^{\text {th }}, 3^{\text {rd }}$ and $2^{\text {nd }}$ groups and the corresponding dressing per cent are $78.14 \pm 0.91, \quad 77.91 \pm 0.25, \quad 76.49 \pm 0.53$ and $73.29 \pm 0.51$, respectively.

The dressing per cent is significantly different $(\mathrm{P}<0.01)$ in $2^{\text {nd }}$ group of piglets compared to other groups. The results were similar to earlier reports of ${ }^{5}$ and ${ }^{6}$. However the difference in dressing per cent among $1^{\text {st }}, 3^{\text {rd }}$ and $4^{\text {th }}$ groups are not significant. The meat bone ratio is high in $3^{\text {rd }}$ group followed by $1^{\text {st }}$, $2^{\text {nd }}$ and $4^{\text {th }}$ groups. Meat bone ratios are $3.20 \pm 0.02, \quad 3.07 \pm 0.06, \quad 3.03 \pm 0.05$ and $2.80 \pm 0.05$ respectively. The meat-bone ratio is significantly different $(\mathrm{P}<0.01)$ in $3^{\text {rd }}$ group of piglets compared to $4^{\text {th }}$ group. The present findings were similar to ${ }^{6}$ and contrast to ${ }^{4}$.

Table.1 Effect of weaning on carcass traits of piglets

\begin{tabular}{|l|c|c|c|c|}
\hline & $\begin{array}{c}\text { Conventional } \\
\text { group (Group1) }\end{array}$ & $\begin{array}{c}\text { Early weaned } \\
\text { (Group 2) }\end{array}$ & $\begin{array}{c}\text { Split } \\
\text { weaned heavy } \\
\text { (Group 3) }\end{array}$ & $\begin{array}{c}\text { Split } \\
\text { weaned } \\
\text { light(Group 4) }\end{array}$ \\
\hline Dressing percent & $78.14^{\mathrm{b}} \pm 0.91$ & $73.29^{\mathrm{a}} \pm 0.51$ & $76.49^{\mathrm{b}} \pm 0.53$ & $77.91^{\mathrm{b}} \pm 0.25$ \\
\hline Meat:Bone ratio & $3.07^{\mathrm{b}} \pm 0.06$ & $3.03^{\mathrm{ab}} \pm 0.05$ & $3.20^{\mathrm{b}} \pm 0.02$ & $2.80^{\mathrm{a}} \pm 0.05$ \\
\hline
\end{tabular}

Means with similar superscripts in a row does not differ significantly $(\mathrm{P}>0.05)$ 
Fig.1 Splitting of carcass after evisceration
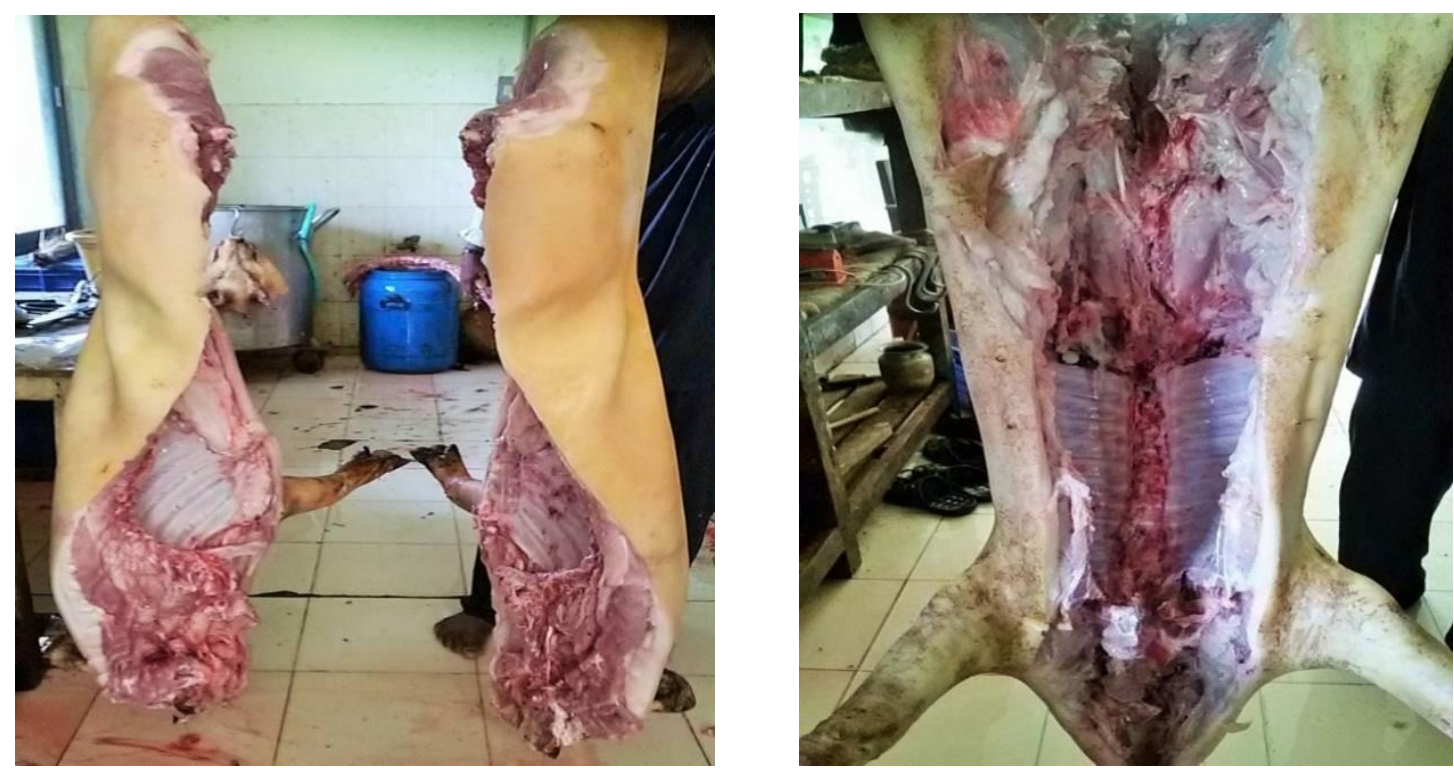

Fig.2 Total meat and bone obtained after separation

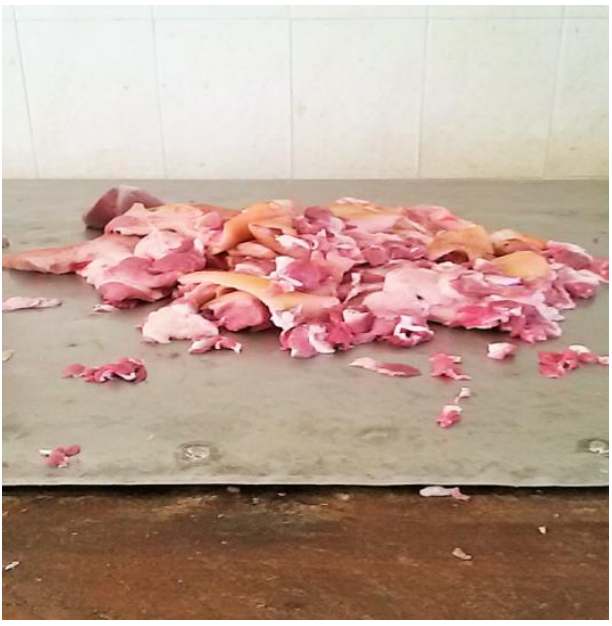

Based on the results obtained in the present study early weaned piglets showed higher feed efficiency over split and conventionally weaned piglets used for pork production.

\section{Acknowledgment}

The authors are thankful to the Sri Venkateswara Veterinary University,

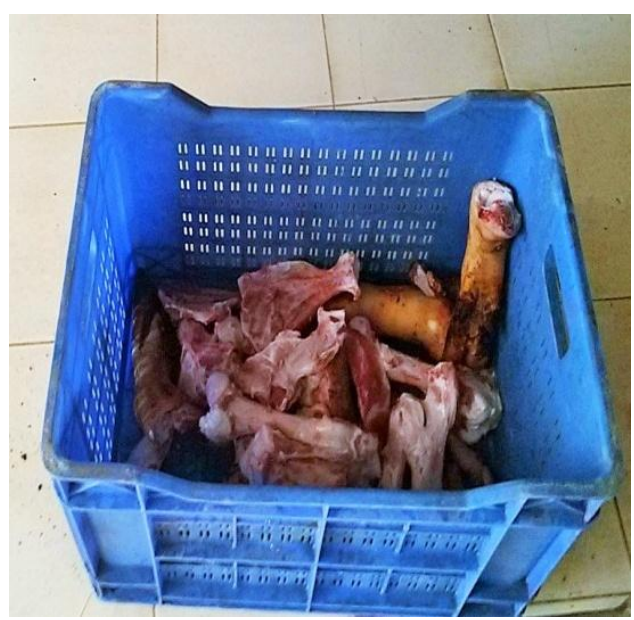

Tirupathi, Andhrapradesh, India for helping hand in successful conduction of research work.

\section{Funding}

The person was supported by RKVY Project through Co-Principal investigator Dr. P. Ashalatha 


\section{Competing interests}

The authors declare that they have no competing interests.

\section{References}

Bahelka I, Hanusova E, Peskovicova D, Demo P 2007 The effect of sex and slaughter weight on intramuscular fat content and its relationship to carcass traits of pigs. Czech J. Anim. Sci, 52:122-129.

Bhat P N, Mohan N H, Sukh Deo 2010 Text Book of pig production 1-17.

Cruz-Bustillo D, Cervantes A, Dieguez F J, Sanchez A, Barreto B 1987 Performance and carcass composition of boars, barrows and gilts slaughtered at 214 or 252 days of age. Ciencia y Tecnicaen la Agriculture, Ganado Porcino, 10:37-55.

Ganelang B, Moreki J C, Tsopito C M, Nsoso S J 2014 Effect of weaning age and sex on bone development of pigs raised under intensive system and slaughtered at $70 \mathrm{~kg}$ body weight Journal of Animal and Feed Research,4: 113-120.

Kumar A and Barsaul C S 1991 Evaluation of best sex and economic slaughter weight on standard feeding in large white pigs under Indian conditions. Asian-Aust. J. Anim. Sci.4:227-230.

Sravanthi V 2014 Thesis submitted to SVVU. USDA (1970) Marketing Bulletin. USDA grades for pork carcasses. Washington, DC.

\section{How to cite this article:}

Ramyasree, I., P. Asha Latha, Ch. Venkata Seshaiah and Srinivas Kumar, D. 2021. Effect of Early and Split Weaning on Carcass traits of Large White Yorkshire Piglets. Int.J.Curr.Microbiol.App.Sci. 10(05): 715-718. doi: https://doi.org/10.20546/ijcmas.2021.1005.080 